\title{
A Histone Deacetylase Inhibitor, FR276457, Altered Characteristics of Infiltrating Cells into Allograft in a Rat Cardiac Transplant Model
}

\author{
Fumitaka Kinugasa ${ }^{1 *}$, Toshiko Yamada ${ }^{2}$, Takahisa Noto ${ }^{3}$, Yasuharu Urano4 and Shoji Takakura1
}

${ }^{1}$ Translational and Development Pharmacology-US, Astellas Global Development Inc. 1 Astellas Way, Northbrook, IL 60062, USA

${ }^{2}$ Astellas Research Institute of America LLC, 8045 Lamon Avenue, Skokie, IL 60077, USA

${ }^{3}$ Drug Safety Research Labs, Astellas Pharma Inc. 2-1-6, Kashima, Yodogawa-ku, Osaka 532-8514, Japan

${ }^{4}$ Chemistry Research Laboratories, Astellas Pharma Inc., Miyukigaoka 21, Tsukuba, Ibaraki 305-8585, Japan

\begin{abstract}
Background: A recent study indicated that FR276457, a pan-histone deacetylase inhibitor, prevented allograft rejection in an ACl-to-Lewis rat heart transplant model, seemingly without affecting cellular infiltration into the transplanted heart. In this report, we investigated alterations in infiltrating cells in allografts by treatment of FR276457.

Materials and Methods: Heterotopic cardiac allografts which were removed from August Copenhagen Irish rats were transplanted into the necks of Lewis rats. FR276457 $40 \mathrm{mg} / \mathrm{kg}$ or vehicle was subsequently administered orally for 5 consecutive days beginning on the operation day after recovery from anesthesia (Day 0 ). The allograft recipients were sacrificed under anesthesia on Day 5 after transplantation. At first, we identified infiltrating cells into the allografts by the histopathological analysis. In addition, we isolated the infiltrating cells from allografts, sorted CD8 positive (CD8 $\left.{ }^{+}\right)$ $T$ cells, and then investigated cytotoxicity of $C D 8^{+} T$ cells against spleen cells from an August Copenhagen Irish rat.
\end{abstract}

Results: Histopathological analysis of allografts on Day 5 after the heart transplant showed that infiltration of $T$ cells was not suppressed in FR276457-treated allograft recipients, compared with those in vehicle-treated allograft recipients, although the infiltration of ED1 positive cells was tended to decrease. Ex vivo analysis revealed that alloantigen-specific cytotoxicity of $\mathrm{CD} 8^{+} \mathrm{T}$ cells, isolated from allografts in FR276457-treated allograft recipients, against $\mathrm{ACl}$ rat splenocytes was much lower than that in vehicle-treated allograft recipients.

Conclusion: FR276457 treatment suppressed the alloantigen-specific cytotoxicity of $\mathrm{CD}^{+} \mathrm{T}$ cells infiltrated into the allograft.

Keywords: Rat heart transplantation; Infiltrating cells; Cytotoxicity; CD8 positive T cells; Histone deacetylase inhibitor

\section{Introduction}

Histone deacetylases (HDACs) are known as modulators of gene transcription via keeping the balance between the acetylated and deacetylated states of chromatin. Acetylated level of chromatin changes gene expression and affects cell conditions [1,2].

It has been reported that histone deacetylases (HDAC) inhibitors induced protein hyperacetylation and caused chromatin remodeling, transcriptional activation and repression, cell-cycle arrest, cell differentiation, and cell death [1,3-6]. In fact, several reports have described the effects of HDAC inhibitors on T cells' proliferation, anergy and differentiation into regulatory $\mathrm{T}$ cells [7-10]. Therefore, an inhibition of HDAC might be a promising biological target for preventing rejection of transplanted organ after transplantation.

We previously reported that a hydroxamic derivative HDAC inhibitor, FR276457 inhibited T cell proliferation as well as activation of THP-1 macrophage-like cells in vitro $[11,12]$. In addition, orally administered FR276457 significantly prolonged allograft survival time in a rat model of heterotopic cardiac transplant [11]. However, despite prolonged survival time, cellular infiltration into the transplanted hearts was observed in FR276457-treated allograft recipients as was in vehicle-treated allograft recipients on Day 5 after transplantation [11].

In this study, we identified the infiltrating cells into the transplanted-heart in FR276457-treated allograft recipients by histochemical analysis. And cytotoxicity of the infiltrating cells isolated from transplanted-hearts in vehicle- or FR276457-treated allograft recipients was investigated.

\section{Materials and Methods}

All animal experimental procedures were approved by the Committee for Animal Experiments of Astellas Pharma Inc.

\section{Experimental animals}

August Copenhagen Irish (ACI) rats (male, 8 weeks), Lewis (Lew) rats (male, 8 weeks) and Brown Norway (BN) rats (male, 8 weeks), obtained from Japan SLC Inc. (Shizuoka, Japan), were used in this study. All animals were given free access to water and standard rat chow ad lib. All animal experimental protocols were approved by the Institutional Animal Care and Use Committee of Astellas Pharma Inc.

\section{Compound}

FR276457 was chemically synthesized at Astellas Pharma Inc. (Tokyo, Japan) [11]. FR276457 was dissolved in 10\% aqueous HCO-60 (vehicle) and orally administered at $40 \mathrm{mg} / \mathrm{kg}$.

\section{Rat heterotopic cardiac transplantation}

Heterotopic cardiac allografts were transplanted using the cuff technique [13]. Briefly, hearts were removed from ACI rats and transplanted into the necks of Lew rats under sodium pentobarbital ( 40 $\mathrm{mg} / \mathrm{kg}$ ) anesthesia administered intra-peritonealy. FR276457 $40 \mathrm{mg} / \mathrm{kg}$ or vehicle was subsequently administered orally via feeding needle for

*Corresponding author: Fumitaka Kinugasa, Translational and Developmen Pharmacology-US, Astellas Pharma Global Development Inc, 1 Astellas Way Northbrook, IL, 60062 USA, Tel: 224-205-5987; Fax: 224-205-5914; E-mail: fumitaka.kinugasa@astellas.com

Received June 20, 2012; Accepted July 10, 2012; Published July 13, 2012

Citation: Kinugasa F, Yamada T, Noto T, Urano Y, Takakura S (2012) A Histone Deacetylase Inhibitor, FR276457, Altered Characteristics of Infiltrating Cells into Allograft in a Rat Cardiac Transplant Model. J Transplant Technol Res 2:111. doi:10.4172/2161-0991.1000111

Copyright: (c) 2012 Kinugasa F, et al. This is an open-access article distributed under the terms of the Creative Commons Attribution License, which permits unrestricted use, distribution, and reproduction in any medium, provided the original author and source are credited. 
Citation: Kinugasa F, Yamada T, Noto T, Urano Y, Takakura S (2012) A Histone Deacetylase Inhibitor, FR276457, Altered Characteristics of Infiltrating Cells into Allograft in a Rat Cardiac Transplant Model. J Transplant Technol Res 2:111. doi:10.4172/2161-0991.1000111

Page 2 of 5

5 consecutive days beginning on the operation day after recovery from anesthesia (Day 0).

\section{Histopathology}

Two allograft recipients $(\mathrm{N}=2)$ from each group were sacrificed under sodium pentobarbital anesthesia on Day 5 after transplantation. Each transplanted heart was removed and then rapidly frozen by immersion in isopentane at $-70^{\circ} \mathrm{C}$. The hearts were sliced into $5-\mu \mathrm{m}$ thick transverse sections. After fixation in $100 \%$ acetone for $10 \mathrm{~min}$ at room temperature, endogenous peroxidase activities were completely suppressed by immersion in $0.35 \% \mathrm{H}_{2} \mathrm{O}_{2} / \mathrm{PBS}$ containing $0.1 \%$ sodium azide for $10 \mathrm{~min}$. Background signals were blocked by incubating tissue sections in PBS containing 10\% normal donkey serum for 10 $\mathrm{min}$. Tissue sections were then incubated for $1 \mathrm{~h}$ at room temperature with either anti-mouse ED1 (macrophage marker) antibody (1:100 dilution; abD Serotec, Kidlington,UK) or anti-mouse TCR (T cell marker) antibody (1:500 dilution; BD Pharmingen, San Diego, CA, USA). After washing, tissue sections were incubated for $30 \mathrm{~min}$ at room temperature with HRP-conjugated anti-mouse IgG (1:150 dilution; Jackson Immunoresearch Laboratories, West Grove, CA, USA). The immunoreaction was visualized using 3,3'-diaminobenzidine and $\mathrm{H}_{2} \mathrm{O}_{2}$ followed by hematoxylin \& eosin counterstaining.

\section{Isolation of effector cells}

Cells were collected from transplanted hearts or spleens of vehicle- or FR276457-treated recipient rats $(\mathrm{N}=3-8)$ on Day 5. Briefly, after harvesting transplanted hearts under anesthesia, the graft was perfused with 5\% FCS PBS and then minced with steel scissors. The minced tissues were suspended and digested in 10\% FCS RPMI 1640 medium (complete medium) including $0.05 \%$ collagenase (SigmaAldrich, St. Louis, MO, USA) and 0.02\% DNase I (Sigma-Aldrich) for $60 \mathrm{~min}$ at $37^{\circ} \mathrm{C}$ in a shaking apparatus. After washing twice with complete medium, viable cells were separated on a Ficoll gradient (GE Healthcare, Tokyo, Japan). Cells were washed three times with complete medium and used as whole graft infiltrating cells (whole cells). T cells (isolated whole T cells) were then collected from whole cells with a $\mathrm{T}$ cell isolating column (Wako Pure Chemical Industries, Ltd., Osaka, Japan), and then $\mathrm{CD}^{+}$and $\mathrm{CD} 8^{-} \mathrm{T}$ cells were isolated using the MACS system (Myltenyi Biotech, Tokyo, Japan). These cells (whole cells, isolated whole $\mathrm{T}$ cells, $\mathrm{CD}^{+}$cells and $\mathrm{CD} 8^{-}$cells) from vehicle- or FR276457-treated recipient rats were used as effector cells for cytotoxic lymphocyte (CTL) assays. Splenocytes from recipient rats were also used as effector cells in some assays.

\section{Preparation of target cells}

Splenocytes were collected from ACI rats, Lew rats, and BN rats. Spleen was removed from each rat $(\mathrm{N}=1)$ aseptically under anesthesia and teased into single-cell suspensions. These splenocytes were then cultured in complete medium containing $1 \mu \mathrm{g} / \mathrm{mL}$ Concanavalin A (Con A) for two days in a humidified atmosphere of $5 \% \mathrm{CO}_{2} / 95 \%$ air at $37^{\circ} \mathrm{C}$. The cells were labeled with $\mathrm{Na}_{2}{ }^{51} \mathrm{CrO}_{4}$ (Amersham Bioscience, Tokyo, Japan) for $1 \mathrm{~h}$, and then after washing 4 times with RPMI medium, splenocytes were re-suspended in complete medium and cultured for $30 \mathrm{~min}$ at the conditions stated above. Splenocytes were then harvested and re-suspended in complete medium, and were used as target cells in CTL assays.

\section{CTL Assay}

CTL assay was performed in round-bottomed 96-well microtiter plates in duplicate. The ${ }^{51} \mathrm{Cr}$-labeled target cells in $100 \mu \mathrm{L}$ complete medium were added to each well at $1 \times 10^{4}$ cells/well. The effector

cells in $100 \mu$ cells/well. The EF were also added to each well in various Effector-to-Target (E: T) ratios (10-300:1). After incubation for $4 \mathrm{~h}$ at $37^{\circ} \mathrm{C}$ in $5 \% \mathrm{CO}_{2}$, the plates were centrifuged at $500 \times g$. The supernatant $(100 \mu \mathrm{L})$ was then harvested, and the radioactivity was measured with a gamma counter. Percent lysis was determined according to the following equation:

$\%$ lysis $=\left[\left(\right.\right.$ Mean value of ${ }^{51} \mathrm{Cr}$ release from target cells mixed with effector cells - Mean value of ${ }^{51} \mathrm{Cr}$ release from target cells alone) / (Mean value of ${ }^{51} \mathrm{Cr}$ release after $0.1 \%$ Triton-X treatment - Mean value of ${ }^{51} \mathrm{Cr}$ release from target cells alone) $] \times 100$

$0 \%$ killing: Mean value of ${ }^{51} \mathrm{Cr}$ release from target cells alone

$100 \%$ killing: Mean value of ${ }^{51} \mathrm{Cr}$ release after $0.1 \%$ Triton-X treatment

\section{Statistical Analysis}

Statistical Analysis was not performed in this study.

\section{Results}

\section{Histopathological analysis}

Infiltration of both $\mathrm{TCR}^{+}$cells and $\mathrm{ED} 1^{+}$cells into the transplanted heart (allograft) was observed on Day 5 after transplantation in vehicletreated allograft recipients (Figure 1A and C). Compared to vehicletreated allograft recipients, allografts of FR276457-treated allograft recipients showed similar levels of $\mathrm{TCR}^{+}$cell infiltration, however, levels of $\mathrm{ED} 1^{+}$cell infiltration was tended to decrease (Figure $1 \mathrm{~B}$ and 1D).

\section{Cytotoxicities of the whole cells and splenocytes}

The whole cells isolated from the allografts of vehicle-treated allograft recipients showed cytotoxicity against Con A-stimulated splenocytes taken from ACI rats (alloantigen). The cytotoxicities at $\mathrm{E}: \mathrm{T}$ ratios of $10: 1$ and $30: 1$ were approximately $11.1 \%$ and $22.6 \%$, respectively $(\mathrm{N}=3)$. However, cytotoxicities of the whole cells isolated

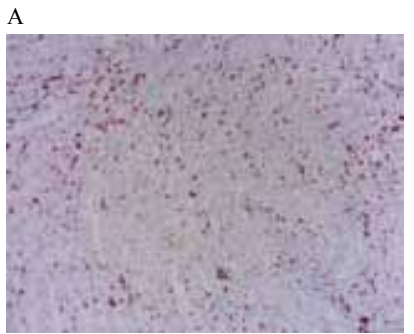

C

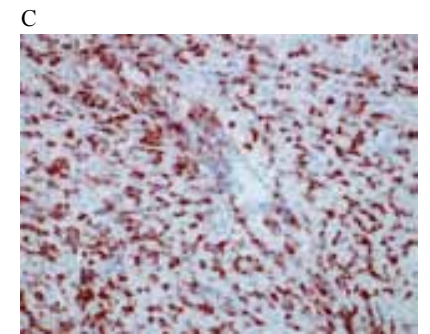

Figure 1: Immune staining for ED1 and TCR. Infiltration of $\mathrm{TCR}^{+}$cells (A) and $\mathrm{ED} 1^{+}$cells $(\mathrm{C})$ were evident in allografts from the vehicle-treated allograft recipients. In the transplanted hearts of FR276457-treated recipient rats, infiltration of $\mathrm{TCR}^{+}$cells (B) remained almost the same, however, infiltration of ED $1^{+}$cells was tended to decrease than that in allografts from the vehicletreated allograft recipients (D). 
from the allografts of FR276457-treated allograft recipients were lower than those from vehicle-treated allograft recipients; cytotoxicities at $\mathrm{E}: \mathrm{T}$ ratios of $10: 1$ and $30: 1$ were approximately $-0.8 \%$ and $4.6 \%$, respectively $(\mathrm{N}=3)$ (Figure 2A).

Splenocytes prepared from both the vehicle- and FR276457-treated allograft recipients as effector cells showed little cytotoxicity against target cells taken from an ACI rat $(\mathrm{N}=1)$ (Figure $2 \mathrm{~B}$ ) and this was reproducible (data not shown). Both the whole cells and splenocytes from vehicle-treated allograft recipients or FR276457-treated allograft recipients as effector cells showed no cytotoxicities against splenocytes as target cells taken from a Lewis rat (auto-antigen) or a BN rat (third party) (data not shown).

\section{Cytotoxicities of the whole $\mathrm{T}$ cells, $\mathrm{CD8}^{+} \mathrm{T}$ cells, and CD8- $\mathrm{T}$ cells}

Cells, isolated from four vehicle-treated allograft recipients or four FR76457-treated allograft recipients, were pooled and used as effector cells for CTL assay.

The whole $\mathrm{T}$ cells isolated from the allografts of vehicle-treated allograft recipients showed cytotoxicity against Con A-stimulated splenocytes of ACI rats. The cytotoxicities at E:T ratios of 10:1 and 30:1 were approximately $11.1 \%$ and $25.8 \%$, respectively $(\mathrm{N}=4)$. However, cytotoxicities of the whole cells isolated from the allografts of FR276457treated allograft recipients were lower than those from vehicle-treated allograft recipients; cytotoxicities at E:T ratios of 10:1 and 30:1 were approximately $3.1 \%$ and $9.7 \%$, respectively $(\mathrm{N}=4)$ (Figure $3 \mathrm{~A}$ ).

Cytotoxicities of $\mathrm{CD}^{+} \mathrm{T}$ cells isolated from vehicle-treated allograft recipients were somewhat stronger than those of the whole $\mathrm{T}$ cells from the same recipient, and were $32.3 \%$ and $49.8 \%$ at E:T ratios of 10:1 and 30:1, respectively. Cytotoxicities of $\mathrm{CD}^{+}$cells from the FR276457-treated allograft recipients were also lower than those from vehicle-treated recipients, which were about $22.0 \%$ and $32.4 \%$ (Figure $3 \mathrm{~B}$ ). The decrease in the cytotoxicity of $\mathrm{CD}^{+} \mathrm{T}$ cells from the allografts of FR276457-treated allograft recipients was observed in deferent E:T ratios. The cytotoxicity for $\mathrm{CD}^{+} \mathrm{T}$ cells from vehicletreated allograft recipients was $36.1 \%$ and $47.7 \%$ at E:T ratios of $12.5: 1$ and 25:1, respectively, while that of $\mathrm{CD}^{+}$cells from the FR276457treated allograft recipients was about $12.3 \%$ and $22.4 \%$, respectively $(\mathrm{N}=4)$ (Figure 3C). CD8- T cells, either from the grafts of vehicle- or FR276457-treated allograft recipients, did not show cytotoxicity against ACI rat splenocytes (data not shown).

\section{Discussion}

Banff classification, the most widely-used scoring system for describing renal allograft biopsies, states that cellular infiltration is an important indication of acute rejection [14]. In an ACI-to Lewis rat heart transplantation model, severe infiltration was also observed in a rejected heart of a vehicle-treated allograft recipient, while none was noted in the functioning heart of this model treated with Tacrolimus, an immunosuppressant used for preventing rejection of transplanted organs [11]. However, while administration of FR276457 at $40 \mathrm{mg} / \mathrm{kg}$ prolonged allograft survival time significantly from a median of 5 to 21 days in an ACI-to-Lewis rat heart transplantation model, obvious cellular infiltration was observed in allografts of FR276457-treated recipient rats [11]. Therefore, we investigated the infiltrating cells into the transplanted heart and their function of cytotoxicity in allograft recipients treated with FR276457.

At first, we performed a histopathological analysis in order to identify the infiltrating cells. The results showed that there were $\mathrm{T}$ cells and activated-macrophages as indicated by $\mathrm{TCR}^{+}$and $\mathrm{ED1}^{+}$, respectively. FR276457 did not affect the number of infiltrating $\mathrm{TCR}^{+}$cells (Figure 1A and 1B). On the other hand, the infiltration of $\mathrm{ED}^{+}$cells into allograft seemed somewhat lesser in the allograft of FR276457-treated allograft recipient rats than those of vehicle-treated allograft recipient.

We next investigated the cytotoxicity of the infiltrating cells isolated from the allografts using a CTL assay. In this assay, various E:T-ratios were examined to confirm cytotoxicity of effector cells. The whole cells isolated from the vehicle-treated allograft recipients as effector cells showed clear cytotoxic activity against target cells from ACI rat (Figure 2A) in E:T-ratio-related manner, but not against target cells from Lewis rat or BN rat (data not shown). Especially the $\mathrm{CD} 8^{+} \mathrm{T}$ cells from the vehicle-treated allograft recipients showed the strong cytotoxicity (Figure 3B and 3C). These results indicate that infiltrating $\mathrm{CD}^{+} \mathrm{T}$ cells in allograft had acquired alloantigen specificity and the $\mathrm{CD} 8^{+} \mathrm{T}$ cells were the main cytotoxic cells of the whole cells and the whole $\mathrm{T}$ cells. On the other hand, alloantigen specific cytotoxicity of $\mathrm{CD}^{+} \mathrm{T}$ cells from the FR276457-treated allograft recipients was strongly suppressed at all E:T-ratio, compared to that of the vehicle-treated allograft
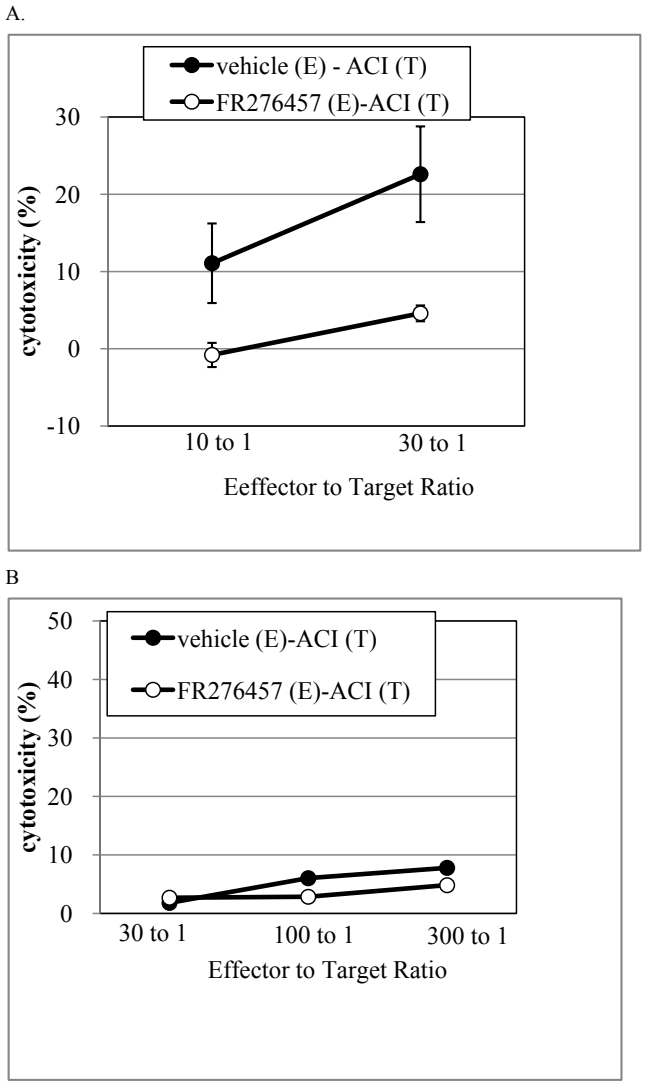

Figure 2: Cytotoxicity of infiltrating cells (whole cells) into the transplanted hearts and splenocytes from vehicle- or FR276457-treated allograft recipients. The infiltrating cells (whole cells) into the transplanted hearts of the vehicle-treated allograft recipients showed cytotoxicity against splenocytes as target cells derived from $\mathrm{ACl}$ rat (A). The cytotoxicity of whole cells into the transplanted hearts of FR276457-treated allograft recipients was suppressed $(A)(N=3$ in each group, respectively). Splenocytes as effector cells from vehicle- or FR276457-treated allograft recipient showed little cytotoxicity against target cells from $\mathrm{ACl}$ rat $(B)(N=1$ in each group respectively). The studies were carried out at different Effector/Target ratios (E:T ratio; 10 to 1 and 30 to 1 ) to confirm the activity of effector cells. 

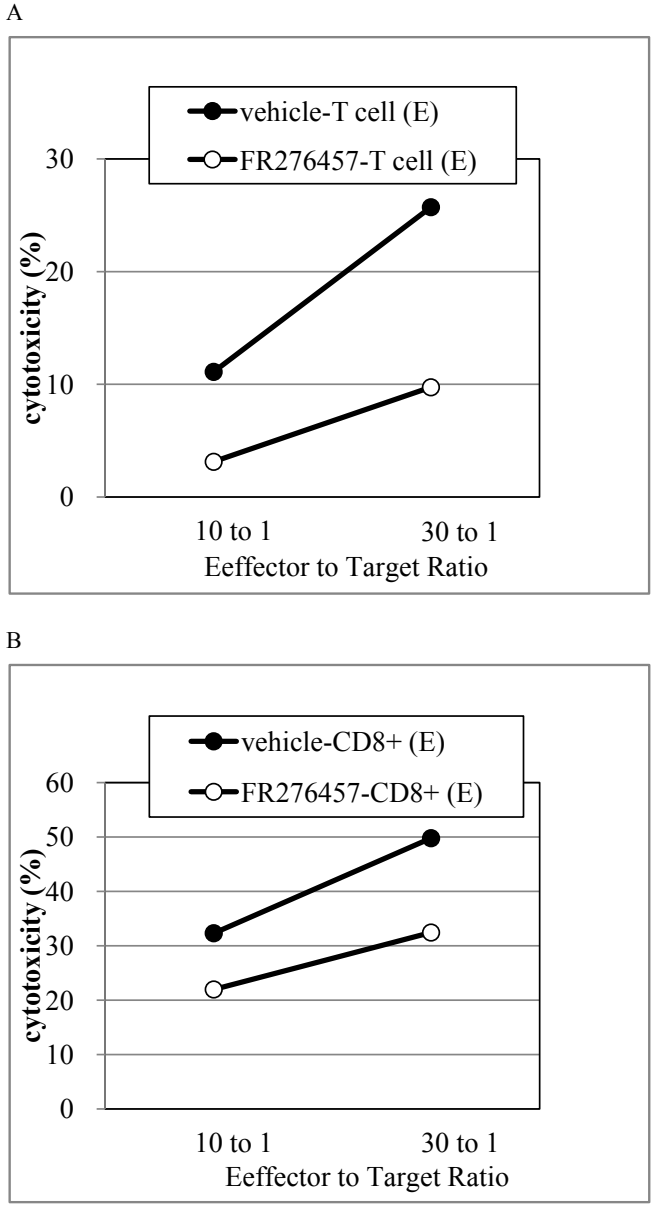

$\mathrm{C}$

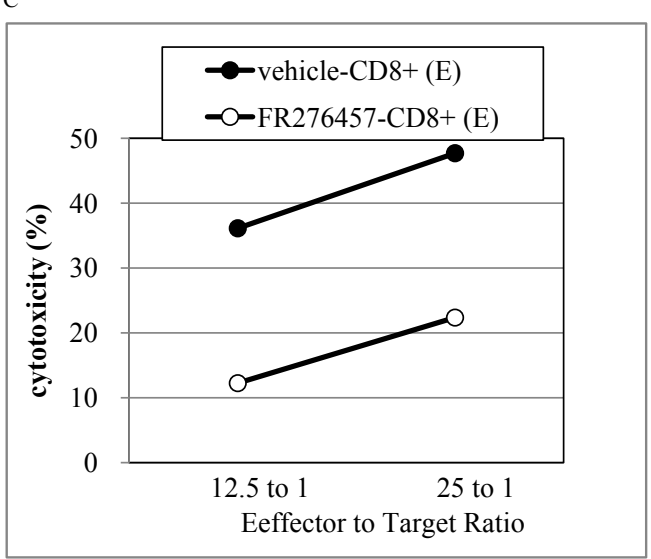

Figure 3: Cytotoxicity of infiltrating whole $\mathrm{T}$ cells and $\mathrm{CD}^{+} \mathrm{T}$ cells isolated from the transplanted hearts. The whole $T$ cells isolated from transplanted hearts in vehicle-treated allograft recipients showed obvious cytotoxicity against splenocytes as target cells derived from $\mathrm{ACl}$ rats. However the cytotoxicity of the isolated whole T cells from FR276457-treated allograft recipients was weaker than those from vehicle-treated allograft recipients (A). The cytotoxicity of $\mathrm{CD}^{+} \mathrm{T}$ cells isolated from FR276457-treated allograft recipients against splenocytes from $\mathrm{ACl}$ rat was also weaker than those from vehicle-treated allograft recipients $(B, C)$. In each experiment, effector cells, isolated from four allografts of vehicle-treated allograft recipients or FR276457-treated allograft recipients, were pooled and used. The studies were carried out at different E:T ratios ( 10 to 1 and 30 to 1 for Figure $3 A$ and $3 \mathrm{~B}$, and 12.5 to 1 and 25 to 1 for Figure $3 \mathrm{C}$ ) to confirm the activity of effector cells. recipients (Figure $3 \mathrm{~B}$ and $3 \mathrm{C}$ ). With these results, it was suggested that FR276457 protected the allograft through prevention of acquisition of antigen specific cytotoxicity of $\mathrm{CD}^{+} \mathrm{T}$ cells, although FR276457 does not inhibit infiltration of $\mathrm{CD} 8^{+} \mathrm{T}$ cells into transplanted grafts.

In our histopathological analysis, the infiltration of $\mathrm{ED} 1^{+}$cells (activated macrophages) into allografts was tended to decrease in FR276457-treated allograft recipients compared to those of vehicle (Figure 1C and 1D). We previously reported that FR276457 suppressed production of MCP-1 (monocyte chemotactic protein-1), that leading macrophage infiltration in the kidney injured model [12]. Therefore, it is considered that FR276457 might suppress macrophage infiltration in this transplant model through the decrease in MCP-1 production. This suppression likely contributed to lengthened graft survival time, since macrophage phagocytosis of the allograft causes significant tissue damage during acute rejection [15].

In this report, we investigated the infiltrating cells in transplanted hearts of vehicle-treated recipient rats and FR276457-treated recipient rats. As results, we found out that FR276457 suppressed the alloantigenspecific cytotoxicity of the infiltrating $\mathrm{CD} 8^{+} \mathrm{T}$ cells. This suppression may be exerted by preventing differentiation of naive $\mathrm{CD}^{+} \mathrm{T}$ cells into antigen-specific $\mathrm{CD} 8^{+} \mathrm{T}$ cells. It was considered that the alteration of $\mathrm{CD}^{+} \mathrm{T}$ cells by FR276457-treatment contributed to the prolongation of graft survival in a rat cardiac transplant model.

\section{Acknowledgements}

We thank Shigeki Satoh, Naoki Ishibashi and Kazunori Kamijo for the strategy for the synthesis of FR276457.

\section{References}

1. Johnstone RW (2002) Histone-deacetylase inhibitors: novel drugs for the treatment of cancer. Nat Rev Drug Discov 1: 287-299.

2. Remiszewski SW (2002) Recent advances in the discovery of small molecule histone deacetylase inhibitors. Curr Opin Drug Discov Devel 5: 487-499.

3. Hassig CA, Tong JK, Fleischer TC, Owa T, Grable PG, et al. (1998) A role for histone deacetylase activity in HDAC1-mediated transcriptional repression. Proc Natl Acad Sci USA 95: 3519-3524.

4. Kijima M, Yoshida M, Sugita K, Horinouchi S, Beppu T (1993) Trapoxin, an antitumor cyclic tetrapeptide, is an irreversible inhibitor of mammalian histone deacetylase. J Biol Chem 268: 22429-22435.

5. Taunton J, Hassig CA, Schreiber SL (1996) A mammalian histone deacetylase related to the yeast transcriptional regulator Rpd3p. Science 272: 408-411.

6. Yoshida M, Kijima M, Akita M, Beppu T (1990) Potent and specific inhibition of mammalian histone deacetylase both in vivo and in vitro by trichostatin A. J Biol Chem 265: 17174-17179.

7. Takahashi I, Miyaji H, Yoshida T, Sato S, Mizukami T (1996) Selective inhibition of IL-2 gene expression by trichostatin A, a potent inhibitor of mammalian histone deacetylase. J Antibiot (Tokyo) 49: 453-457.

8. Mishra N, Brown DR, Olorenshaw IM, Kammer GM (2001) Trichostatin A reverses skewed expression of CD154, interleukin-10, and interferon-gamma gene and protein expression in lupus T cells. Proc Natl Acad Sci U S A 98 2628-2633.

9. Gilbert KM, Wahid R, Fecher NP, Freeman JP, Fifer EK (2000) Potential clinica use of butyric acid derivatives to induce antigen-specific $T$ cell inactivation. $J$ Pharmacol Exp Ther 294: 1146-1153.

10. Tao R, Hancock WW (2007) Regulating regulatory T cells to achieve transplant tolerance. Hepatobiliary Pancr Dis Int 6: 348-357.

11. Kinugasa F, Yamada T, Noto T, Matsuoka H, Mori H, et al. (2008) Effect of a new immunosuppressant histon deacetylase (HDAC) inhibitor FR276457 in a rat cardiac transplant model. Biol Pharm Bull 31: 1723-1726.

12. Kinugasa F, Noto T, Matsuoka H, Urano Y, Sudo Y, et al. (2010) Prevention of renal interstitial fibrosis via histone deacetylase inhibition in rats with unilatera ureteral obstruction. Transpl Immunol 23: 18-23. 
Citation: Kinugasa F, Yamada T, Noto T, Urano Y, Takakura S (2012) A Histone Deacetylase Inhibitor, FR276457, Altered Characteristics of Infiltrating Cells into Allograft in a Rat Cardiac Transplant Model. J Transplant Technol Res 2:111. doi:10.4172/2161-0991.1000111

Page 5 of 5

13. Marni A, Ferrero ME (1988) Heart and kidney transplantation in the rat using a mixed cuff-stent microsurgical technique. Am J Surg 155: 590-593.

14. Racusen LC, Solez K, Colvin RB, Bonsib SM, Castro MC, et al. (1999) The Banff 97 working classification of renal allograft pathology. Kidney Int 55: 713723.
15. Jose MD, Ikezumi Y, van Rooijen N, Atkins RC, Chadban SJ (2003) Macrophages act as effectors of tissue damage in acute renal allograft rejection. Transplantation 76: 1015-1022. 